\title{
POLITIKAI KOMMUNIKÁCIÓ ÉS EXPRESSZIVITÁS
}

\author{
Szabó Gabriella \\ (Társadalomtudományi Kutatóközpont Politikatudományi Intézet) \\ Kiss Balázs \\ (Társadalomtudományi Kutatóközpont Politikatudományi Intézet) \\ Tanulmány beérkezett: 2020. október 4., opponálás: 2020. október 13-31., \\ véglegesítve: 2020. november 4.
}

\begin{abstract}
ÖSSZEFOGLALÓ
Az írás a Politikai kommunikáció és expresszivitás címú tematikus blokk bevezető tanulmánya. Feladata, hogy meggyőzze az olvasókat az érzelemtelített politikai kommunikáció jelentőségéről, illetve új szemléletmód bevezetésének szükségességéről. Az expresszivitás a politikai kommunikációnak azon aspektusa, amely lefedi a kommunikátor saját viszonyát a kommunikáció többi összetevőjéhez. A viszony nyilvánosságra hozatala lehet szándékos, ekkor múködésbe léphetnek a célracionalitás mechanizmusai, más esetekben a kommunikátor manipulációs szándék nélkül nyilvánul meg, ekkor a pszicho- és szociolingvisztika lehet segítségünkre. Meglátásunk szerint az expresszivitás megértéséhez a Roman Jakobson-i funkcionális kommunikációelmélet megfelelő kiindulópont, amelyet azonban a célracionalitáson túli cselekvéselméletekkel érdemes kiegészíteni, mint például az Erving Goffman

által kidolgozott dramaturgiai cselekvés, illetve a pszichológiából ismert ventilálás.
\end{abstract}

Kulcsszavak: expresszivitás — igazmondás — kommunikációs funkciók @ politika

"A szememben lévő könnyek az elszántság, a düh és az erő könnyei."1

„Dühös vagyok, mert attól, hogy minden iskola egyforma lesz, a gyerekeink még nem lesznek egyformák. (-)"2

„Gyurcsány egy moral insanity. Magyarul szarházi. Minden indulat nélkül mondom."3

„Ö a mi kis Blankánk, a jövö politikusasszonya, ugye, aki ha gimnazista, akkor maximum 18 éves lehet, és már egy igazi, kretén, barom állat, szerencsétlen, nyomorult, ócska, rohadt, kis proli." ${ }^{\prime 4}$

"\#O1g

A politikai vélemények kinyilvánításakor a megszólaló egyrészt a szabadságjogait gyakorolja, másrészt azonban konfliktushelyzetekre is reagál, mégpedig egyéni vagy társas önkifejezés segítségével. A tanulmány a politikai vélemények nyilvános megfogalmazását nem a jogok vagy egyéb normatív keretrend- 
szer alapján közelíti meg, hanem az önkifejezés, azaz az expresszivitás irányából. Célunk tehát a politika és az expresszivitás kapcsolatát a kommunikáció nézőpontjából vizsgáló kutatások elméleti kiindulópontjainak felvázolása.

A társadalom- és kultúrakutatók az új millennium korai éveitôl rögzítik az önkifejezés nyilvánosságát biztosító infrastruktúra bővülését - web 2.0, közösségi média, betelefonálós politikai músorok, fogyasztói értékelésekre alapuló információs portálok, egyre szélesedő internetes kommentvilág, új tiltakozási formák, stb. -, illetve a politikai vélemények kinyilvánítását bátorító gesztusok gyarapodását (Stanyer, 2006; Szabó-Kiss, 2012; Merkovity, 2018: 31; Gerencsér-Szúts, 2020). A közéleti kérdésekben kifejtett álláspontok így az önmegvalósítás részeként értelmeződnek, és további, olyan pozitív kontextusban emlegetett fogalommal társulnak, mint bátorság, magabiztosság, felszabadultság, kreativitás, egyéni stílus (Kim-Sherman, 2007).

Immár nemcsak arról van szó, hogy az állampolgárok kisebb-nagyobb csoportja felindult és tiszteletlen módon önti szavakba elégedetlenségét, vagy heves fellobbanással tudatja egy-egy politikussal a rokonszenvét. Aligha kérdéses, hogy a tanulmányunk legelején felidézett megszólalások a politika részét képezik, tehát méltóak a politikatudomány érdeklődésére. Vannak további, a politikai kommunikáció eddigi kereteit másképpen feszegető példáink is. Az egyik közelmúltbeli eset Pokorni Zoltán érzelmes megnyilvánulása ${ }^{6}$ egy holokauszttal kapcsolatos rendezvényen, a másik az az eseménysor, amely az Országgyúlésben, ${ }^{7}$ majd a Magyar Televízió épületében ${ }^{8}$ zajlott ellenzéki képviselők főszereplésével 2018 decemberében. De nem kevésbé figyelemre méltó az, hogy az online politizálásban és a közösségi médiában szinte alig találunk olyan állampolgári társalgást, amelyik ne fordulna egy idő után, vagy mindjárt a legelején trágárságba, érzelmi kitörésbe, a középosztályi etikett szerint modortalannak minősíthető megnyilvánulásokba.

Bizonyos értelemben nem új jelenségekről van szó, hiszen 1990-ben is elsírta magát az akkori magyar honvédelmi miniszter egy nyilvános rendezvényen, 2006-ban nem utolsó sorban az akkori miniszterelnök kiszivárogtatott trágárságai okoztak konsternációt, és amióta létezik az internet azon modortalan állampolgári társalgások folynak. A politikatudomány múvelői előtt a negatív és pozitív érzelmi kitörések tehát az utóbbi évtizedekben is ismertek voltak. Mégis, jobbára tudományos érdektelenség vette körül a témát, a közbeszéd minőségével kapcsolatban inkább a gyưlöletbeszéddel, az antiszemitizmussal és cigányellenes retorika leleplezésével kapcsolatos vizsgálatok domináltak (Gerő, 2001; Pál, 2012; Glózer, 2013; Bernáth-Messing, 2017). Hasonlóképp a nemzetközi szakirodalomban: az egyénileg megélt érzelmek politikai véleményként történő kifejezéseit az elmúlt években kezdték el feltérképezni - főleg amerikai esettanulmányok segítségével (Berry-Sobieraj, 2014; Mutz, 2015; Sydnor, 2019). 
Ebben a tanulmányban és a tematikus blokk többi írásában azt mutatjuk be, milyen lehetne az a fogalomegyüttes és az a módszerkészlet, amelyik hozzásegíthet az érzelmektől átfütött kommunikációs aktusoknak a leírásához. Mielőtt azonban a terület kutatásának lehetséges útjait felvázoljuk, röviden bemutatjuk, miért nem elegendők az ez ideig alkalmazott elemzési eszközök a feladat elvégzéséhez.

\section{IGAZMONDÁS ÉS MANIPULÁCIÓ, AVAGY MIÉRT NEM HASZNÁLHATÓ A POST TRUTH-KONCEPCIÓ?}

Az emóciókat középpontba helyező politikai megszólalások vizsgálatához új eszközökre van szükség, mert a jelenleg rendelkezésünkre álló keretek vagy gyenge lábakon állnak vagy megkérdőjelezhetők a kiindulópontjaik (Kiss, 2013; Papacharissi, 2015; Andok, 2020). Miközben ugyanis a politikatudomány tudott arról, hogy vannak trágár kiszólások, érzelmes megnyilvánulások, s általában szólva a politikai kommunikációs aktusok nemigen elégítik ki az igazmondás vagy a deliberáció követelményeit, hajlamos volt az ilyen normasértő vagy meghökkentő jelenségeket egyszerúen a manipuláció (Breton, 2000) fogalmával illetni, vagyis olyan meggyőzésre irányuló erőfeszítésnek tekinteni, amelyik nem teszi a célpont számára világossá, hogy véleményváltozás elérésére törekszik.

Különösen felerősödött ez az attitűd 2016 óta, ugyanis a közbeszédnek ekkortól az egyik szóbokra a post-truth, a tények utáni világ, a fake news és még egy sor fogalom. Némelyek politikatudományi jelentőséget is tulajdonítottak a fejleményeknek (Krekó, 2018; Kalpokas, 2019), jóllehet kétséges, hogy van-e alapja a post-truth koncepciójának. ${ }^{9}$

A post-truth elképzelés korszakhatárt sugall: mintha 2016-ig a politikai igazmondás korában éltünk volna, mert addig a politikusok és a média tartotta magát a tényszerúség, az adatokra alapuló és racionális kommunikáció normájához. Volt normasértés, de nagyon ritkán, például kampányok idején, és azt is diszkurzíve vagy egyéb szabályozással szankcionálták. Mindenesetre értékesebbnek tartották azt, ha a kommunikátor igazmondással akart támogatást szerezni, mint ha torzítással, érzelmek - például félelem és remény felhorgasztásával (Brader, 2006). Utóbbit a Platónig visszanyúló politikatudományi és politikai filozófiai hagyomány alapján el szokás ítélni, éspedig szintén manipulációnak, demagógiának minősítve.

Aki a hamisság és a manipuláció keretében akarja magyarázni például az állampolgári, de akár a politikusi megnyilvánulásokat, az rejtetten vagy nyíltan azt feltételezi, hogy a politikai kommunikációs aktusoknak egyetlen igazi funkciója a valóság hư leírása. A világleírás pedig alávethető az igaz-hamis kérdésének. 
Arisztotelész két hagyatéka: igazmondás és politika

Az igazmondás paradigmája egészen Platónig ${ }^{10}$ és Arisztotelészig vezethető vissza. Mi most csak Arisztotelésszel foglalkozunk, mert úgy látjuk, hogy az ő munkássága két hagyománynak a forrása: az igazmondásé, és az ez alá nem vehető megnyilvánulások elítéléséé, mint az Platónnál olvasható.

Arisztotelész a Herméneutika című múvének 4. fejezetét a következő megjegyzéssel zárja: „... nem minden mondat kijelentés, hanem csak az, amelyre vonatkozik az, hogy igaz vagy téves. Márpedig ez nem mindre vonatkozik; például a kérés mondat ugyan, de nem is igaz, nem is téves. A többit hagyjuk, hiszen vizsgálatuk inkább a szónoklattanba vagy a költészettanba tartozik." (17a)

A megjegyzés értékeléséhez érdemes látni, hogy itt és az Organon további szövegeiben Arisztotelész a tapasztalati és a logikai ítéletekkel foglalkozik, vagyis olyan "mondatokkal”, amelyekről vagy tapasztalati, vagy logikai úton egyértelmúen eldönthetők, hogy igazak-e vagy sem. Arisztotelész véli, hogy ezeken kívül is vannak mondatok, ám azok a retorika és a poétika alá tartoznak, mert nem érvényes rájuk az igaz-hamis, vagyis az általunk igazmondásnak nevezett kritérium. Ez nemcsak arra utal, hogy nem minden mondattal kapcsolatban van értelme feltenni az igazmondás kérdését, hanem arra is, hogy a politikai kommunikáció jelentős részével kapcsolatban sincs ennek értelme. Mind a retorika, mind pedig a poétika ugyanis jelentős részben politikai vagy politikai jelentőségü szövegekkel foglalkozik.

Arisztotelész Rétorika címú múve kifejezetten a politikai kommunikáció kérdéseire vonatkozik, ha tehát ideutalja az igazmondás alá nem vonható kijelentéseket, akkor a politikai kommunikáció túlnyomó részét is kivonja a kritérium alól. Háromféle beszédet különböztet meg: a tanácsadóit, a törvényszékit és a bemutatót, de mindhárom típushoz jelentős részben, mai szóval politikai beszédek tartoznak, ugyanis a törvényszékeken szintén nem kis részben politikai ügyeket tárgyalnak, ahogyan ez Szókratész peréből, de máshonnét is ismert (Ober 1991, 1993; Bolonyai, 2003). A Poétika, Arisztotelész másik releváns múve pedig elsősorban a tragédia szabályait mutatja be, márpedig a korabeli Athénban a színházi előadások politikai jelentőségúek, ami ha másból nem, abból látható, hogy az „állam” fizet a nézőknek napidíjat, hogy jelen legyenek az előadásokon (Fischer-Lichte, 1990). ${ }^{11}$

Leszögezhetjük, hogy Arisztotelész a politikai kommunikációs jelenségek túlnyomó részére nem tartotta relevánsnak az igazmondás kérdését. Ezt támasztja alá a Rétorika is a maga szintén kettős álláspontjával. Arisztotelész a fejtegetés legelején (1254a) óva int attól, hogy a rétor érzelmeket keltsen a bírákban, tehát a népgyưlésen és a törvényszéken majd döntést hozó athéni polgárokban, ugyanis ez eltorzítja a tisztánlátásukat. Csakhogy ezt követően több száz oldalt ír arról, hogy hogyan lehet a bírákban érzelmeket kelteni, mert „Az érzelmek azok a tényezők, amelyek megváltoztatják az emberek ítéleteit..." 
(1378a). A mú nagy része nem más, mint azoknak az Arisztotelész szerint általánosan elfogadott véleményeknek, ha úgy tetszik, közhelyeknek, és a tapasztalat alapján érzelmeket kelteni tudó technikáknak a leírása, amelyekkel befolyásolhatók a döntnökök, a közönség. A retorika ugyanis a közönségre irányul, olyannyira, hogy még a három retorikai típus sem a maga formális szabályai szerint különbözik egymástól, hanem a közönség milyensége miatt (1358b). Nem az számít tehát, hogy mi a tudományos vagy filozófiai igazság, hanem az, hogy mit hajlandó a közönség elfogadni, megszavazni.

Az előbb Platón által negatíve, majd Arisztotelész által pozitíve elindított két hagyomány egyike tehát a tapasztalati és logikai ítéleteké, a világról szóló igaz és hamis mondatoké, és erre épül például a nyelvészet kétezer éves iránya. A másik pedig a nem ide tartozó kijelentéseké, mondatoké, amit Arisztotelész a Poétikába és a Rétorikába utal, és ami tulajdonképpen egészen a XX. század közepéig inkább marginális marad a nyelvészetben is a világ helytálló leírásához, konstatálásához képest. A későbbi terminológiát használva úgy fogalmazhatunk, hogy Arisztotelésznél egyszerre van jelen a beszéd világleíró, ezért az igazmondásnak alávethető, más szóval referenciális vagy informatív funkciója, és a közönségre irányuló, annak érzelmeit megváltoztatni akaró, más szóval konatív funkciója. ${ }^{12}$

Az igazmondás paradigmája tehát nem elegendő akkor, amikor a felfütött és sorozatosan normasértő megnyilvánulások jelenkori elszaporodását akarjuk értelmezni. Egy-egy adatközlés esetében viszonylag könnyen utána lehet járni annak, hogy helyes-e vagy sem, érzelmi kirohanások, szubjektív megnyilvánulások helytállóságát azonban aligha ellenőrizhetjük. Paradox módon az érzetekre, benyomásokra építő megszólalások is az igazságra apellálnak, csak éppen nem tényalapú, ellenőrizhető, objektív igazságra, hanem az autenticitás és az empátia által felfogható igazságra. Joggal feltételezhetjük, hogy a politikusok, elkötelezett újságírók vagy érdekképviseleti csoportok valóban manipulálni akarnak, tehát az ő emotív megnyilvánulásuknak gyưjtőfogalma lehet a manipuláció, hiszen átgondolt stratégiai kommunikációt folytatnak, nem pedig hirtelen elragadtatásuk vált véletlenül vagy akaratuk ellenére nyilvánossá. Ám hasonló tudatosságot aligha feltételezhetünk az online vitához hozzászóló vagy tüntetéseken skandáló állampolgárok esetében. ${ }^{13}$ Vajon, amikor a politikus azt látja, hogy az érzelmek kinyilvánítása és a szélsőséges szubjektivitás az állampolgárok által buzgón alkalmazott és elfogadott stílus, miért ne gondolhatná azt, hogy ő is megnyilvánulhat őszintén? Meglehet, hogy az ôszinte érzelmi állapotok kifejezése a politikusok és az újságírók közegében stratégiai és manipulatív megfontolást követ, de az adott pillanatban lehet olyan, amelyik éppen azért megnyerő, mert nem érződik rajta a patikamérlegen történő adagolás. Éppen ettől tûnik és válik autentikussá sokak szemében. ${ }^{14}$ 
A dolgozat elejének idézetei tehát nem marginális nyelvi jelenségek, hanem teljes értékú politikai kommunikációs aktusok. A megszólalók performálják a maguk jogosultságát a megszólalásra, élesen elítélnek, minősítenek, és felszólítanak másokat, s nem az számít, hogy vajon igazolható-e az, amit a közösségi médiában posztolnak, felírtak a táblájukra, belekiabáltak a nagygyưlés terébe vagy szónoklatuk részeként elmondanak. Hogyan is lehetne igazságpróba alá vetni szubjektív viszonyulásokat? Elegendő az aktusok puszta megtörténte, az, hogy a megszólalók így érzik és így gondolják, ott és akkor lehetőségük van sokak füle hallatára és szeme láttára kinyilvánítani. Ezek az aktusok pedig az igazmondás legitimációja nélkül is képesek hatni.

\section{A KOMMUNIKÁCIÓ FUNKCIÓI: NYELVTUDOMÁNYI ÖRÖKSÉG BÜHLERTŐL JAKOBSONIG}

Hogy a világleírás paradigmája mennyire uralkodó a XX. század elején is, mutatja, hogy például Edward Sapir, akinek a nevét utóbb a Sapir-Whorf tézis is kölcsönvette, még a húszas években is azt írja (Sapir, 1921: 14.), hogy a nyelvészet számára másodlagos az, ami nem értékelhető az igazmondás alapján, ezért másodlagosak a megszólalásban megnyilvánuló érzelmek. Ezzel szakít Karl Bühler. Bühler olyan nyelvfelfogással áll elő, amelyik szerint minden kommunikáció egyszerre szól a világ valamely részletéről, érzékelteti a megszólalónak a dologgal és a kommunikációval kapcsolatos szubjektív állapotát, valamint hat a megszólalás hallgatójára. Ekként a nyelv nem választható el a kommunikációs helyzettől, tehát sem a megszólalótól, sem a hallgatótól, vagyis nem zárt, formális rendszer, ami a valóságot képezi le és nem tesz semmi mást. „Az emberi beszéd háromszoros feladatot lát el: kinyilvánitás, kiváltás és bemutatás." - írja Bühler (1965: 1. és 28.).

Látjuk, hogy még csak nem is elsőként említi az addig paradigmatikusnak minősült (világ)bemutatást [Darstellung], ehelyett a kinyilatkoztatást [Kundgabe], vagyis a beszélő szubjektív állapotának kifejezését helyezi az élre, és a hallgató érzelmeinek, reakciójának kiváltását [Auslösung] említi másodiknak. Minden megszólalás egyszerre végzi el mindhárom feladatot [Leistung]: minden megszólalás mond valamit a világról, kifejezi a megszólaló mentális állapotát, és kivált valamit a hallgatóból. Bühler nem azt mondja, hogy vannak olyan verbális megnyilvánulások, amelyek a világ objektív tényeiről szólnak, mások a beszélő szubjektív állapotát fejezik ki, megint másokkal pedig a beszélő nem tesz mást, mint hat a hallgatóra, hanem azt mondja, hogy a nyelvi megnyilvánulás mindig egyszerre teljesíti mindhárom feladatot. ${ }^{15}$

A társadalomtudományok körében jól ismert Austin beszédaktus elmélete. Ennek végkövetkeztetése szintén az, hogy a nyelv belefonódik a kommunikációs körülményekbe, és ezért ugyanaz a mondat vagy verbális megnyilvánulás 
a legkülönbözőbb jelentésekre tehet szert és változatos hatást kelthet attól függően, hogy milyen kommunikációs helyzetben hangzik el. Az ismert példa az anyakönyvvezető mondata arról, hogy az előtte megjelenteket házastársaknak nyilvánítja. Ennek a mondatnak akkor van valós következménye, akkor tekinthető sikeresnek, ha a megfelelő kommunikációs és intézményes feltételek állnak fenn, például nem valamilyen filmfelvétel részeként hangzik el, és a tisztviselő fel van jogosítva a házasság megkötésére.

A beszéddel tehát egyáltalán nem csak leírjuk, jól vagy rosszul, a világot, hanem cselekszünk vele, performálunk valamit. Egy sor esetben ki is mondjuk, hogy mit cselekszünk éppen, például azt mondjuk, hogy „Ígérem, hogy elmegyek!” vagy azt mondjuk, hogy "Állítom, hogy ez történt.” - ilyenkor úgynevezett performatív igéket ('igérem, állítom) használunk, szemben azzal az esettel, ha csak annyit mondunk, hogy „Elmegyek!” vagy „Ez történt.” Mint látszik, az egyszerú világleíró mondatokkal is cselekszünk, hiszen megszólalunk, és kiemelünk valamilyen említésre méltó dolgot a világ egészből, erre irányítjuk rá a partnerünk figyelmét: „ez történt és nem más”. Bühlerhez viszszakapcsolva: nemcsak mondunk valamit tárgyakról és a dolgok állásáról, hanem kifejezzük azt, hogy éppen most mi érdekel, mi foglalkoztat bennünket a világból, és felhívjuk valamire a minket hallók figyelmét.

Austin nyomán a nyelvészeti pragmatika különféle csoportokba sorolta és sorolja a beszédaktusokat. Talán legismertebb ezek közül Searle (1997) ötös felosztása. Az egyszerú megállapításokat asszertívumoknak nevezi, a parancsokat direktívumoknak, a beszélő általi vállalásokat komisszívumoknak, a beszélő érzelmi állapotát kifejezőket expresszívumoknak, végül a házasságkötéshez hasonló megnyilatkozásokat deklarációknak. Mint Bühler és Austin esetében, itt is az a fontos, hogy a világleírás már messze nem az egyetlen funkciója a kommunikációnak, és a többi fajta valóban kívül esik az igazmondás kritériumán.

A funkciók szaporodásának a csúcspontja Roman Jakobson felfogása, aki a kommunikációt illetően hat tényezőt és hat funkciót különböztet meg. A kiindulópont bühleri, hiszen Jakobson szerint is minden kommunikációs aktusban, különösen amennyiben terjedelmesebb, egyszerre van jelen hat tényező és tényezőnként egy-egy, tehát hat funkció. A hat tényező a beszélő, a hallgató, a téma, amiről a kommunikáció zajlik, a közös kód, amely által megértik egymást a felek, a kommunikációs kapcsolat, tudniillik az, hogy hallják és látják egymást, valamint az üzenet, amely tehát a beszélőtől eljut a hallgatóhoz. A kommunikációban a hangsúly a hat tényező bármelyikére helyeződhet, jobbára valamelyik inkább van az előtérben, mint a többi.

Az informatív funkció főségéről beszélünk akkor, ha a kommunikáció a világról, valamely dologról, tudniillik a kommunikációs folyamaton kívül levő dologról szól, azt írja le, annak a képét közli. Ha a hallgató áll a középpontban, akkor a konatív funkció túlsúlyáról beszélünk. A kommunikáció rá akarja venni 
valamire a hallgatót: javasol, kér, parancsol és így tovább, közvetlenül vagy közvetetten el akar érni nála valamit. Általában nem nélkülözhetetlen, hogy performatív igék (javasolom, kérem, parancsolom stb.) szerepeljenek a megszólalásokban, mert a konvenciók vagy a percepció alapján kiviláglik, hogy a hallgatónak meg kellene tennie valamit. Gyakori, hogy a kommunikációs folyamat az éppen használt jeleket, szavakat, vizuális eszközöket, ezek jelentését és értelmét akarja tisztázni. Ilyenkor nagy hangsúly esik a metaszemiotikai funkcióra. Jakobson metalingvisztikai funkciót említ, mivel azonban nemcsak verbális kommunikáció elemzése a célunk, hanem vizuálisé is, ezért inkább a metaszemiotikai megnevezést használjuk. Nem ritka kommunikációs folyamat az, amelyik látszólag például a történések leírását adja elő, valójában arra szolgál, hogy fennmaradjon a kommunikációs kapcsolat; ez a fatikus funkció teljesítése. Különösen fontosnak tûnik ez a funkció a közösségi média esetében (Miller 2008 és 2015, Porter 2017), ahol érvényesülni látszik a posztolásnak az a szerepe, hogy fennmaradjon a kapcsolat, hogy az érdeklődők, az ismerősök legközelebb is ellátogassanak az oldalra. De fatikus funkció a kommunikációs kapcsolat felmondásának vagy megtagadásának a kinyilvánítása is.

Ha az üzenet megformáltsága ötlik szembe, akkor a kommunikációs aktus elsősorban poétikai funkciót lát el. Amennyiben a szöveg túl míves, vagy nem eléggé érthető, amennyiben egy kép túlságosan tarka vagy éppen nagyon fakó, általában: amennyiben a tartalom megformálása inkább tûnik fel, mint maga a tartalom, akkor a poétikai funkció nyomakodott az előtérbe - függetlenül attól, hogy azt akarta-e valaki is vagy sem. Végül, ha a beszélő kap prioritást, akkor a kommunikáció elsősorban expresszív funkciót lát el. A megnyilvánulás szólhat bármiről, valamilyen tényállásról a világban, az éppen használt jelek, szavak, képek értelméról, lehet mívesen formált vagy csúnya stb., ami a legszembetûnőbb, az a beszélő szubjektív állapota, érzései, viszonyulása ahhoz, amirôl szó esik, vagy a kommunikáció bármely más tényezőjéhez.

A kommunikáció tehát feladatokat lát el: kifejez érzelmeket, felszólít másokat, leír tényállást, jelzi, hogy él a kommunikációs kapcsolat, értelmezi és tisztázza a használt jeleket, és hatásosabbá teszi a mondandót azzal, hogy odafigyel a megformáltságára. Vannak verbális és nem verbális megnyilvánulások, amelyek például a rövidségük okán csak egy-egy funkciót látnak el, és sokszor ezek segítségével szokták megvilágítani Jakobson elméletét. Mindig figyelembe kell azonban venni azt, hogy csak ritkán van jelen egyetlen funkció akár a hétköznapi társalgásokban, akár a politikai megnyilvánulásokban. Ugyanakkor vagy a szándék, vagy a recepció vagy a konvenció alapján az adott kommunikációs aktusnak lehet elsődleges, másodlagos stb. funkciója, vagyis elemezhetô az, hogy mi a funkciók hierarchiája. Az adott társalgásban vagy az adott politikai aktor megnyilvánulásaiban kialakuló, a belőlük kiolvasható funkció-hierarchia mintái leírhatók, és ez alapján összehasonlíthatók egymással társalgások és megszólalók mind térben, mind időben. 
A nyelvészet történetének a rövid áttekintésével azt kívántuk megmutatni, hogy habár nem alap nélküli a mai közírók és a fősodorba tartozó politikatudomány részrehajlása a politikai kommunikáció igazmondás-paradigmáját illetően, létezik más paradigma is. A nyelvészet a XX. századra kialakított számos olyan fogalmat és megközelítést, amelyikből kiindulva képesek lehetünk érdemben kezelni az igaz-hamis kritérium alá nem vonható kommunikációs aktusokat. Immár bevett felfogás, hogy a nyelvnek, illetve a kommunikációnak csak az egyik funkciója a világról igaz, ellenőrizhető íéleteket tenni lehetővé, illetve alkotni. A többi funkció figyelembe vételével gazdagabb képet nyerhetünk a politikai kommunikációs és a politikai folyamatok világáról.

\section{CSELEKVÉSELMÉLETEK A CÉLRACIONALITÁSON TÚL}

Merész párhuzammal élve azt mondhatjuk, hogy a nyelvészetéhez hasonló bővülésen mentek keresztül a társadalmi és politikai cselekvéssel kapcsolatos elméletek is a XX. század folyamán, itt is egyetlen paradigmától jutottak el a cselekvés többféleségének elfogadásáig. Ennek rövid áttekintése következik most.

Első ránézésre éppen ellentétes folyamat játszódott le. Max Weber (1987: 2. §) még négyféle cselekvést különböztetett meg, ezzel szemben az ötvenes évektôl kezdve például a választáskutatás már azt is kényszernek érezte, hogy az addig kizárólagosan alkalmazott célracionális, instrumentális cselekvés mellé fel kellett, hogy vegyen egy másikat is, azt, amit expresszív választásnak neveztek el. Mintha Weber négyességétől tehát legalább egy időre a célracionális cselekvés egyedülvalóságáig jutottunk volna el, a helyzet azonban ennél összetettebb. Habermas (2011) Schluchter (1981) nyomán azt olvassa ki Weber négyes tipológiájából, hogy valójában ott a célracionális típus az etalon, a másik három ennek az összetevőiből rendelkezik egyenként kevesebbel és kevesebbel. A társadalomtudományok paradigmatikus cselekvéselmélete tehát Weber miatt és óta a célracionalitás (Demertzis 2017: 1-2.), éspedig vagy azért, mert ki tudják mutatni, hogy maga a cselekvő is tudatosan célracionálisan cselekszik, vagy azért, mert a kutató képes racionális célt találni a vizsgált cselekvéshez és aztán azt visszavetíteni a cselekvő tudatába. A célracionalitás paradigma státusa tehát nem azt jelenti, hogy minden cselekvés célracionális, hanem azt, hogy bármilyen legyen is a cselekvés, a célracionális alapján érdemes megérteni.

Az alábbiakban azt mutatjuk be, ahogyan - a nyelvészethez hasonlóan - a társadalomtudományok cselekvéselméleti palettája is színesebb lett, egyre kevésbé voltak képesek beérni a célracionalitással, mint paradigmával. Először a választási paradoxont említjük és ennek megoldásaként az expresszív választás problémáját, ami átviszi a gondolkodást az expresszív cselekvés fogalmához, majd a Goffman által kidolgozott dramaturgiai cselekvést mutatjuk be. 


\section{A választási paradoxon és az expresszí politikai cselekvés}

Nagyjából az austini fordulattal egy időben merül fel a politikatudomány választásokkal foglalkozó részében a kétely, hogy vajon miként lehet megmagyarázni az állampolgárok választási részvételét (Downs, 1957). A fő kérdés az, hogy egyáltalán miért mennek el választani, amikor az egyéni szavazatuk csekély hatást gyakorol a végeredményre, ugyanakkor a részvétel, főleg, ha beleértjük az alternatívákkal kapcsolatos ismeretgyújtést is, költséges, energiát és időt vesz el az egyéntől. Márpedig a célracionális cselekvés paradigmája szerint az állampolgár minden politikai cselekvése alkalmával számba veszi a politikai, így a választási részvételének a költségeit és hasznát, és csak akkor lép, ha a haszon meghaladja a költségeket. Mivel pedig ez sosem történik meg, ezért a célracionalitás nem magyarázhatja a választási részvételt.

A vizsgálódók válasz gyanánt bevezetik az expresszív választás fogalmát. Eszerint az állampolgár nem a költséget és a hasznot nézi, hanem ki akar fejezni valamit a részvételével, éppenséggel függetlenül attól, hogy a szavazata számít-e a végeredmény alakulásában vagy sem. Több dolgot is ki akarhat nyilvánítani, így például a párthoz kötődését, a pártidentitását (Fiorina, 1976: 396.), vagy azt, hogy fontos számára a közösség egysége (Rosanvallon, 1992: 38-39.), vagy azt, hogy fegyelmezett állampolgár, aki elfogadja, hogy a választási részvétel növeli a megválasztottak legitimitását.

Rögtön látjuk, hogy az expresszív választás fogalma tulajdonképpen nem lép ki a célracionalitás és így az instrumentális választás logikájából. Itt is a választás vagy a részvétel nem más, mint eszköz, éspedig racionálisan kiválasztott eszköz, csak éppen nem a választás eredményének az eldöntéséhez, hanem valamilyen egyéni jó érzéshez. Mint az instrumentális választás, ez is utilitárius tehát. ${ }^{16}$

Hasonló ambivalenciával találkozunk a politikatudomány egyik területén, amely kifejezetten az expresszív politikai cselekvés kérdésével foglalkozik, éspedig szembeállítva a saját felfogását az instrumentális racionalitás szemléletmódjával. Például Jakob Svensson (2008a és 2008b) azt mondja, hogy az állampolgárok azért vesznek részt a helyi közéletben, mert ki akarják fejezni az identitásukat. Kutatásában helsingborgi szülők közéleti tevékenységét vizsgálja, és bár a velük készített interjúkban ez a megokolás sosem hangzik el az alanyok részéről, Svensson mégis arra következtet, hogy a megkérdezettek a "gondos szülő" identitásukat akarják kifejezni, és ezért vesznek részt olyan kezdeményezésekben, amelyek meg akarják óvni a környékük egy részét a beépítéstől, hogy a gyerekeknek legyen hol játszaniuk. Volna tehát egy előzetesen létező identitás, amelyet aztán a szülő a politikai részvételén keresztül akar kinyilvánítani, és ezt nevezi Svensson expresszív cselekvésnek. Zhao és munkatársai (2008) és Bene Márton (2020) hasonlóképpen arra jut, hogy a 
Facebookon az állampolgárok fel akarják mutatni az identitásukat, de ezt inkább implicite teszik, mint explicite.

Ezekkel a kísérletekkel kapcsolatban világos, hogy amennyiben az állampolgár explicite megmondaná a kutatónak, hogy neki a részvétellel az identitásának a felmutatása a célja, akkor ez célracionálissá, instrumentálissá tenné a cselekvését. A kutatónak tehát arra van szüksége, hogy az állampolgár ne tudjon arról, hogy neki ilyen identitással kapcsolatos célja is van, hanem ezt a kutató olvashassa ki a részvételből. Eszerint az állampolgár ki akar valamit fejezni, de mivel nem tudja, hogy mit akar valójában kifejezni azon túl, amit leír vagy megtesz, sőt, azt sem tudja, hogy ki akar valamit fejezni, ezért a kutató szabadon értelmezheti a történést expresszív és nem célracionális cselekvésnek.

Azt a gondolatmenetet látjuk ezekben a próbálkozásokban, ami egyszerre veti el és tartja fenn a politikai cselekvővel kapcsolatos antropológiai premiszszát, a célracionális ember képét, csak éppen az egyik cél helyett egy másikat definiál kívülről a cselekvő számára. Ugyanakkor fontos ez a módosulás, mert felveti az akaratlan expresszivitás, a tudattalan, a nem reflektált kifejezés lehetőségét. A politikai élet számos pillanata lehet olyan, ahol a cselekvők nem akarnak semmi specifikust kifejezni, csupán reagálnak, kinyilvánítják az identitásukat, a szubjektív viszonyukat a történésekhez. Nem szükséges feltételeznünk, hogy minden cselekvő az intézmények vagy más állampolgárok viselkedését akarja befolyásolni a cselekvésével, beérhetjük azzal, hogy egyszerüen kifejezi azt, amit érez, kinyilvánít valamit.

\section{A dramaturgiai cselekvés és az udvariasság}

Ugyanez az ambivalencia, tehát a stratégiai/célracionális expresszív viselkedés és az önkéntelen expresszivitás kettőssége figyelhető meg Erving Goffman elméletében. ${ }^{17}$

Goffman (2000) azt mondja, hogy az egyén mindig valamilyen szerepet vesz magára, amikor mások szeme elé kerül. A helyzet tehát azonos a politikai kommunikációs helyzetekkel, éspedig még abban a szokványos értelemben is, hogy a politikus szerepet játszik, mint színész a színházban. Csakhogy a goffmani elméletben a színházmetafora nem terjed ki a közönségre, ugyanis nála a közönség az alakítás aktív részese, nemcsak passzív szemlélő, mint a színházban, ahol legfeljebb tapsolni tud. Ez a tényező különösen alkalmassá teszi Goffman elméletét arra, hogy a közösségi médiabeli politikai kommunikációt vizsgáljuk, hiszen itt is meglehetősen sűrű interakció zajlik a politikus, vagy bármely posztoló és a közönsége, vagyis az ismerősi köre között: az ismerősök lájkolják, kommentálják, megosztják, mémesítik a posztjait, és persze maguk is profilt gondoznak a felületen. 
Goffman nemcsak arra mutat rá, hogy az egyén kialakít egy arculatot, homlokzatot, ${ }_{1}^{18}$ és azt fordítja a közönsége felé, tehát tudatos, célracionális expreszszív cselekvést hajt végre, hanem arra is, hogy a közönség is részt vesz ennek az egyéni arculatnak a formálásában, de legalábbis a megvédelmezésében. Ez utóbbi azt jelenti, hogy a közönség még akkor is az egységes arculat szerint kommunikál az egyénnel, amikor az valami olyat tesz, ami ellentétben áll az arculatával; a közönség hajlamos úgy tenni, mintha az ilyen bakikat nem venné észre.

Számunkra a felfogás legfontosabb eleme az, hogy Goffman egyszerre tekinti akaratlagosnak és akaratlannak az arculatképzést és annak védelmezését mind az egyén, mind a közönsége részéről. Vagyis az egyén és a közönség viselkedése nem tekinthető egyszerú színlelésnek, vagyis igazmondás helyett hamisságnak, autentikus helyett instrumentális és stratégiai viselkedésnek a saját mineműségét, társadalmi státusát, érzéseit és ismereteit illetően. Ahogyan Goffman egyik példája (2000: 49.) sugallja: az orvos nem azért tart fenn olyan homlokzatot, mely szerint emlékszik minden betege minden leletére, mert be akarja őket csapni, hanem azért, mert ezt igénylik tőle a betegei. Persze nem is játssza tökéletesen ezt a szerepet, de nemcsak azért nem, mert képtelenség minden beteg összes adatára emlékezni, hanem mert a homlokzatápolás jelentős részben akaratlanul történik, ráadásul részt vesz benne az éppen vele kommunikáló beteg is, aki meg az engedelmes és az orvost kritikátlanul tisztelő ember arculatát mutatja akarva-akaratlanul az orvos felé.

A goffmani felfogás újra lehetővé teszi a számunkra annak az elgondolását, hogy nemcsak tudatos és akaratlagos cselekvések lehetnek fontosak akár a hétköznapokon, akár a politikában, ami egyre inkább hétköznapi önmagában is az internet és a közösségi média jóvoltából. A másik fontos kiindulópontunkká pedig az tehető, ahogyan a homlokzat gondolatból kinőtt az udvariasság- és az udvariatlanságelmélet, jóllehet ezek explicite célracionális cselekvőket feltételeznek. Ez is azoknak a pontoknak az egyike, ahol összetalálkozik a nyelvészet a cselekvéselméleti eredményekkel. Goffman is ír arról, hogy a közönség tapintatos az egyénnel szemben: ritkán kérdőjelezi meg az egyén által sugalltakat. Az udvariasság a vonatkozó nyelvészeti, pragmatikai felfogás szerint hasonlóképpen abban áll, hogy a közvetlen kommunikációban a felek legalábbis nem sértik meg a másik által felmutatott szerepet, sőt, gyakran további gesztusokkal még meg is erősítik azt. Az udvariasságelmélet klasszikus változatának (Brown-Levinson, 1987) az arculatot fenyegető cselekvés az antropológiai kiindulópontja, az udvariasság ennek a fenyegetésnek az elhárítása, az erről való lemondás a felek részéről.

Mindez azért releváns, mert a tanulmány elején idézett megszólalások aligha tekinthetốk udvariasaknak, és jó lenne olyan módszerrel rendelkezni, amelynek a segítségével leírhatók, csoportosíthatók az ilyen megnyilvánulások, hanem azért is, mert az udvariatlanság nemcsak verbális módon, hanem például vi- 
selkedésként is megmutatkozhat (Culpeper, 1996: 357-358.). Felismerhetővé válnak azok az esetek, amelyeknél a megszólalás csak implikálja a homlokzat megtámadását, vagyis a beszélő nem ragadtatja magát az idézetekkel párhuzamba állítható durvaságra, mégis udvariatlan aktust követ el. Például ha a politikust egy női munkatársának a leváltásáról kérdezik, amire ő azt válaszolja, hogy nem foglalkozik nőügyekkel, akkor egy ilyen kijelentés jól elemezhető az udvariasságelméletek segítségével, például megállapítható a súlyossága a trágár megszólalásokéhoz képest (Brown-Levinson, 1987: 76. skk.).

Ebben a részben a cselekvéselméleteket tekintettük át, azért, hogy megmutassuk, a XX. század második felére nemcsak a nyelvészetben érett meg az idő arra, hogy a diszciplínák megszabaduljanak a vezető paradigmájuk, a társadalomtudományok esetében a célracionálisan cselekvő ember paradigmájától. A túllépés elgondolhatóvá teszi azt, hogy az emberek a közéletben is ragadtathatják magukat olyan cselekedetekre, amelyek a legreménytelibben nem a célracionalitás etalonja segítségével vizsgálhatók. Mindezzel nem azt sugalljuk, hogy a célracionális cselekvés - akár mint valós történés, akár mint elemzési paradigma - elvetendő, vagy háttérbe szorítandó. Valószínúleg minél inkább intézményes politikai aktorral, tehát politikussal vagy médiamunkatárssal van dolgunk, annál inkább fogunk jól kitapintható stratégiai cselekvésekre találni, és ezért a célracionalitás paradigmájának az alkalmazása továbbra is szükséges. Ugyanakkor az állampolgárok, az online világban tömegesen megjelent új szereplők, új megközelítésmódokat is alkalmazandóvá tesznek a kutatások számára és ehhez fel kell tételeznünk más cselekvéstípusokat és nyelvi funkciókat.

\section{POLITIKAI KOMMUNIKÁCIÓ ÉS EXPRESSZIVITÁS - KUTATÁSI IRÁNYOK, SZEMPONTOK, LEHETŐSÉGEK}

A fentiek nyomán számunkra az expresszivitás mindenekelőtt a kommunikációnak az az aspektusa, amely lefedi a kommunikátor saját viszonyát a kommunikáció többi összetevőjéhez, tehát a világhoz, a partnerhez, a megformáláshoz és a kommunikációs kapcsolathoz. Ez a viszonyulás lehet érzelemtelített és lehet mérsékelt, alig feltűnő, de akármilyen is, mindig gyakorol hatást, akár akarja a kommunikátor és a környezete, akár nem. Vannak kommunikációs esetek, amikor ezt a funkciót a kommunikátor tudatosan felerősíti, tehát sokkal kevésbé amiatt nyilvánul meg, mert mondani vagy jelezni akar valamit a világgal kapcsolatban, mint inkább avégett, hogy jelezze saját viszonyát a kommunikációs helyzethez. Más esetekben a kommunikátor tudattalanul nyilvánul meg, fejezi ki a viszonyát a világhoz. Megint máskor a kommunikátor nem akar semmi specifikust kifejezni, de a környezet, így a közönsége vagy a kutató, az információtartalmon túl is kiolvas valamit abból, ahogyan az illetô viselkedett, megnyilvánult. 
Mint a korábban a dramaturgiai cselekvésről írottakból kitetszhetett, kutatásunk további központi fogalma a goffmani interakció. A politikai kommunikációt interakciónak, interakciók sorozatának tekintjük. Nem annyit jelent tehát számunkra az interakció-központúság, hogy az egyének hatnak egymásra. Nézőpontunk az interakciót helyezi a középpontba, vagyis azt követjük, ahogyan ez alakul, függetlenül attól, hogy melyik szereplő milyen előzetes tervvel lépett kapcsolatra a többiekkel, hogyan tartott ki az álláspontja mellett vagy változtatott azon, mikor lépett be, mikor távozott, és vajon miért. Habár egy aktor mondhat igazat, vagy tévedhet, hazudhat, fóleg a politikus és az újságíró pedig nagyon is akarhat hatni, az interakció egésze és egyes szekvenciái sem nem az informativitás, sem nem a hatáskeltés funkciójával írhatók le kimerítően, inkább ezek és további funkciók összességével. Legfeljebb anynyit feltételezhetünk, hogy az egyes funkciók aránya, összetétele módosul a társalgás folyamán.

Az elemzéseinkhez tehát nem szükséges azt feltételeznünk, hogy például a posztoló avégett nyilvánul meg érzelmi alapon, hogy valamilyen specifikus hatást váltson ki az ismerőseiből vagy az odakeveredőkből. A cselekedetének lehet tudatos vagy tudattalan oka és célja az egyszerü kifakadás, a gőz leeresztése (Mor et al., 2015). A kommunikáció expresszív funkciójára fókuszáló vizsgálatok így a viselkedéslélektan irányából is megtámogathatók. Az online kommentkultúra terjedésével figyeltek fel ugyanis a nyilvános ventilálás jelenségére (Crockett, 2017). A tézis szerint a megszólalások jelentős részében a felgyülemlett feszültség és negatív érzelmek kiadása és levezetése történik. Egy-egy konfliktushelyzetre adott válaszként emberek egy részében felmerül az igény a harag és a frusztráció kibeszélésére. A ventilálást az önmegsegítés vágya táplálja: a szabad és korlátok nélküli önkifejezéstôl az alany azt reméli, hogy kimozdítja a kellemetlen érzések köréből, megszabadítja a diszkomforttól és képessé teszi a továbblépésre (Voggeser et al., 2018). A ventiláció modellje tehát feltételez egy erősen felfokozott érzelmi állapotot, amit a megszólaló gátlástalanul, mindenféle előzetes kalkuláció nélkül kommunikál, annak reményében, hogy ez enyhülést hoz számára (Bushman, 2002; Gentile, 2013). Az internet biztosította körülmények kiválóan alkalmasak a ventilálás funkciójának betöltésére: gyorsan, egyszerúen és olcsón elérhető felületek, könnyen elhagyható online közösségek és anominitás.

Noha kevés kutatás áll rendelkezésre, úgy tûnik, hogy az online felületeket ventilálás céljából használók rövidtávon valóban hasznát látják az érzelmeik szabadon engedésének, a posztolás után nyugalomról és megelégedésről számolnak be. Ellentétes hatás mutatkozik azonban mások online ventilálásának olvasásával: ebben az esetben a közönség tagjainak felindultsága erősödik. A harag, a düh és a frusztráció kifejezésének kettős hatása van: a megszólaló pillanatnyi megnyugvásban részesül, míg a befogadók izgatottsága nő (Martin et al., 2013). Bár a pszichológia kifejezetten károsnak tartja a nyilvános és szak- 
mai kontroll nélküli ventilációt, a napjainkban oly népszerủ lelki egészség programok, asszertív kommunikációt hirdető tanácsadások, az érzékenység felvállalására buzdító self-help könyvek és a populáris kultúra önkifejezésre buzdító produktumait láthatóan nehéz ignorálni.

Az expresszív politikai kommunikáció kutatása a szándékok - legyenek azok manipulatívak, önkifejezők vagy a feszültség levezetését szolgálók - helyett mindenekelőtt a társalgásra és annak hatásaira irányítja a figyelmet. A nyelvészeti összefoglaló végén azt jeleztük, hogy Roman Jakobson felfogását tekintjük eligazítónak a nyelvi expresszivitás kapcsán. A jakobsoni alapok tehát a megszólaló személyes érzelmi állapotát és viszonyulásait kifejező fordulatok - bővíthetők néhány egyéb aspektussal.

Az érzelem és a politikai kommunikáció kapcsolatának vizsgálatában a legkézenfekvőbb a szövegben fellelhető érzésekre utaló igék, jelzők és főnevek összegyújtése és elemzése (Koschut, 2017). A legegyszerúbb a vizsgálni kívánt érzelmekhez kapcsolódó szavak listáját elkészíteni, majd pedig manuálisan rögzíteni azok előfordulását. Nagyobb méretű anyagokat számítógépes módszerrel elemezhetünk. Az érzelemlexikont számítógép segítségével is futtathatjuk, vagy egy előre kiválasztott szövegkorpuszon betanított osztályozó algoritmusokat használhatunk (Haselmayer-Jenny, 2017).

A politikai kommunikáció kutatásában a leggyakrabban a szentimentelemzéssel találkozhatunk, e módszer azonban nem teljesen fedi le az érzelmek vizsgálatának teljes spektrumát (Drávucz-Szabó, 2017): az adott szövegekben a megszólaló pozitív, semleges vagy negatív viszonyulásának valamelyikét kívánja azonosítani. Ettől eltérően az emócióelemzés előre meghatározott érzelemkifejezési kategóriákat létesít, és azokat azonosítja a szövegekben. Például az undor emóciójához kapcsolható az "elhányom magam, ha ránézek”, a szeretethez az "oda vagyok érte" vagy az örömhöz a "el vagyok ragadtatva” szófordulat. Az emócióelemzés képi ága azokon a leírásokon alapul, amelyeket Ekman és Friesen (1969) adott arról, hogyan jelenik meg a hat alapérzelem az emberi arcon. Manapság pedig az emotikonok és az emojik politikai használatának vizsgálata dívik (Bódi-Veszelszki, 2006; Kariryaa et al., 2020).

A kutatás másik szintje az érzelmi viszonyulást tükröző konnotációk figyelembevétele (Koschut, 2018). Míg az emócióval teli szavak összegyújtése inkább nyelvészeti munka, ez már némiképpen társadalomtudományi feladat, hiszen egyes szófordulatok érzelmi kontextusát és konnotációját nagyban meghatározza a szokásszerú alkalmazás, a kulturális-társadalmi-politikai közeg, a közlő szándéka és a befogadó recepciója. Magyarországon tipikus példa a roma-cigány vagy a menekült-migráns szóhasználat érzelmi konnotációja. Szokás úgy gondolkodni, hogy a párok előbbi tagja befogadó, támogató, szimpátiát keltő, az utóbbi ellenben sértő, ellenséges, félelemkeltő szándékot leplez.

Mivel az érzelmekre vonatkozó fogalmi rendszerünk metaforikusan szerveződik (Kövecses, 2003), ezért a politikában is megfigyelhető képes beszéd 
erejét jakobsoni értelemben nemcsak a poétikus, hanem az expresszív funkció megvalósulásának is tekinthetjük. A 2011-es politikai változásokat „arab tavasznak" nevező megszólalások reményt sugallnak, míg az Orbán Viktort "diktátornak" nevezők az önkényurak iránti gyülöletet igyekeznek átirányítani a magyar kormányfőre. A metaforák vizuális megjelenítését is emlithetjük: a politikusokat kefebajusszal ábrázoló képi anyagok hasonlóképpen a diktátorokkal szembeni harag transzponálását szolgálják.

Végül, de nem utolsósorban felhívjuk a figyelmet az expresszív kommunikáció és a testi-fizikai érzetek összekapcsolására. Sara Ahmed nyomán tudjuk, hogy a politikai diskurzusokban gyakran alkalmaznak fájdalomra utaló fordulatokat, hogy a trauma segítségével erősítsék meg a politikai identitást (Zombory, 2019). Míg az undort keltő szavak feladata, hogy fizikailag is távolságot teremtsenek a választópolgárok és bizonyos tárgyak, élmények, eszmék vagy embercsoportok iránt (Ahmed, 2004), addig a fizikai közelségre, kontaktusra utaló kifejezések - „nyújtsunk segítő kezet”, ,karoljuk fel”, ,"dolgozzunk együtt”, stb., a szolidaritás és az együvé tartozás érzését kommunikálják (Yuval-Davis, 2011).

Mindezekkel felvértezve olyan kérdések megválaszolására tehetünk kísérletet, hogy vajon érzelmesebb-e, expresszívebb-e a mai politikai kommunikáció, mint a tíz, húsz, harminc évvel ezelőtti volt? Van-e olyan csatorna, amit kifejezetten vagy legalábbis dominánsan az expresszív funkcióra szokás használni? Melyek azok a médiából ismert müfajok és formátumok, amelyek előtérbe helyezik és bátorítják a megszólalók érzelmi viszonyulásainak a kifejezését? A politikai kommunikáció mely szereplői támaszkodnak a kommunikáció expresszív oldalára? Van-e ebben különbség az ellenzék és kormány oldal között? Vajon baloldali vagy jobboldali sajátosság-e az erőteljes expresszivitás? Igaz-e, hogy a kisebb, marginális erőkre jellemzőbbek az emotív kifejezési módok? Melyek azok a politikai témák, amik arra késztetik a beszélőket, hogy véleményüket emocionális és szubjektív megéléseikre hivatkozva fejezzék ki? Milyen politikai cselekvések kapcsolódnak egy-egy érzelem kifejezéséhez?

A Politikatudományi Szemle különszámában olvasható tanulmányok e hosszú út első lépéseit foglalják össze.

\section{JEGYZETEK}

${ }^{1}$ Dobrev Klára beszéde a DK kampánynyitón 2019. április 14. https://www.youtube.com/watch? $\mathrm{v}=\mathrm{uKHkVUfiDkk}$

2 Kunhalmi Ágnes bejegyzése. 2019. július 2. https://www.facebook.com/kunhalmiagnes/posts/ $2923586667656789 /$

3 Deutsch Tamás bejegyzése. 2011. március 29. https://twitter.com/dajcstomi/status/526921909 12196608

${ }^{4}$ Bayer Show. Echo TV 2019. január 13. 
${ }^{5}$ Az O1G betû szerinti jelentése: „Orbán egy geci” Az o1g hashtag a Twitteren terjedt https://twitter. com/hashtag/o1g

${ }^{6}$ https://mandiner.hu/cikk/20200114_igy_vallott_pokorni_zoltan_a_nagyapjarol

${ }^{7}$ https://www.facebook.com/TordaiBencePM/videos/357921591433135/, https://index.hu/belfold/ 2018/12/12/az_ellenzek_elfoglalta_a_parlament_pulpitusat_nem_engedik_a_helyere_az_elnokot/

${ }^{8}$ https://444.hu/2018/12/17/az-mtva-ban-ejszakazott-a-13-ellenzeki-kepviselo, https://444.hu/ 2018/12/17/eloben-kozvetitettek-ahogy-kidobjak-hadhazyt-es-szelt-a-kozmediabol,

9 Egy korai áttekintés: Spohr, 2017. Lásd még Aczél, 2017; Dahlgren, 2018 és De Michelis, 2020.

${ }^{10}$ Lásd például a Phaidrosz második felét.

${ }^{11}$ Ráadásul a retorika és a poétika merev szétválasztása aligha tartható Arisztotelész idejét illetően: Walker, 2000: 8-9 és 17-41.

${ }^{12}$ Smith (1990) konatív helyett poétikai funkciót említ, talán a Poétikára való utalás miatt, talán amiatt, mert nem veszi figyelembe Arisztotelész kijelentését, hogy azért van háromféle retorika, mert háromféle a közönség.

${ }^{13}$ Lásd ehhez például: Jerit et al., 2009: 100.

${ }^{14}$ Enli (2017) egyenesen azt írja, hogy 2016-ban Trump kampánya kevésbé volt professzionális, és éppen ezért tưnt a későbbi elnök autentikusabbnak, mint ellenfele.

${ }^{15}$ Utóbb a bühleri hármasság funkcióhármassággá alakul át, és megnyitja az utat a felé, hogy a nyelvhasználat körülményei is bekerüljenek a nyelvészet érdeklődési körébe. Ennek a nyelvészeti részdiszciplínának pragmatika a neve. Lásd Tátrai, 2011 és 2017.

${ }^{16}$ Engelen (2006: 423. skk.) hasonlóan értelmezi az expresszív választással kapcsolatos próbálkozásokat.

${ }^{17}$ A goffmani kettősséghez lásd például Schleicher, 2020: 169.

${ }^{18}$ A magyar fordítás a homlokzat szót alkalmazza ott, ahol az eredetiben face áll, ezért ehelyütt felváltva használjuk az arculat és a homlokzat szót a face-re.

\section{IRODALOM}

Aczél Petra (2017): Az álhír. Kommentár a jelenség értelmezéséhez. Századvég, 85. szám. 5-25.

Ahmed, Sara (2004): Cultural Politics of Emotion. Edinburgh University Press.

Arisztotelész (1972): Poétika. Helikon Kiadó, Budapest.

Arisztotelész (1979): Organon. Akadémiai Kiadó, Budapest.

Arisztotelész (1982): Rétorika. Gondolat, Budapest.

Andok Mónika (2020): A társadalmi nyilvánosság kutatásának affektív fordulata. Jel-Kép, 2002/2,

22-34. https://doi.org/10.20520/JEL-KEP.2020.2.23

Austin, John L. (1955/1990): Tetten ért szavak. Akadémiai Kiadó, Budapest.

Bene Márton (2020): Virális politika. Politikai kommunikáció a Facebookon. L’Harmattan, Budapest.

Bernáth Gábor-Messing Vera (2017): Biztonsági fenyegetés vagy humanitárius katasztrófa? A po-

litikai jelentésképzés és beszivárgása médiába. Médiakutató, 2017 Tavasz.

Berry, Jeffrey M.- Sobieraj, Sarah (2014): The Outrage Industry. Political Opinion Media and the New Incivility. Oxford University Press, New York. 
Bolonyai Gábor (2003): 44 bekezdés az athéni igazságszolgáltatásról. In: Bolonyai Gábor (szerk): Lysias beszédei. Osiris-Balassi, Budapest.

Bódi Zoltán-Veszelszki Ágnes (2006): Emotikonok. Érzelemkifejezés az internetes kommunikációban. Magyar Szemiotikai Társaság. 142 oldal + CD melléklet. Magyar szemiotikai tanulmányok 9.

Brader, Ted (2006): Campaigning for Hearts and Minds. How Emotional Appeals in Political Ads Work. The University of Chicago Press, Chicago.

Breton, Philippe (1997/2000): A manipulált beszéd. Helikon Kiadó, Budapest.

Brown, Penelope-Stephen C. Levinson (1987): Politeness. Some universals in language usage. Cambridge University Press, Cambridge.

Bushman, Brad (2002): Does Venting Anger Feed or Extinguish the Flame? Catharsis, Rumination, Distraction, Anger, and Aggressive Responding. Personality and Social Psychology Bulletin, Vol 28, No 7, 724-731. https://doi.org/10.1177/0146167202289002

Bühler, Karl (1934/1965): Sprachtheorie. Die Darstellungsfunktion der Sprache. Gustav Fischer Verlag, Stuttgart.

Crockett, M. J. (2017): Moral outrage in the digital age. Nature Human Behaviour, 1, 769-771. Elérhető: https://www.nature.com/articles/s41562-017-0213-3 (letöltés időpontja: 2020. május 10.). https://doi.org/10.1038/s41562-017-0213-3

Culpeper, Jonathan (1996): Towards an anatomy of impoliteness, Journal of Pragmatics, Vol 25, No. 3, 349-367. https://doi.org/doi.org/10.1016/0378-2166(95)00014-3

Dahlgren, Peter (2018): Public Sphere Participation Online: The Ambiguities of Affect - Commentary. International Journal of Communication, 12: 2052-2070, 1932-8036/20180005. https://doi. org/10.3917/enic.024.0005

De Michelis, Lidia (2020): Reflecting on New Media, Post-Truth and Affect through the Lenses of Cultural, Literary and Discourse Studies. Comunicazione Politica, 1.

Demertzis, Nicolas (2013): Introduction: Theorizing the Emotions-Politics Nexus. In: Demertzis, Nicolas (szerk.) Emotions in Politics. The Affect Dimension in Political Tension. Palgrave-MacMillan.

Downs, Anthony (1957): An Economic Theory of Democracy. Harper \& Row, New York.

Drávucz Fanni-Szabó Martina (2017): A beszélói szubjektivitás vizsgálata szentiment- és emóciókorpuszokon. In: Ludányi, Zsófia (szerk.): Doktoranduszok tanulmányai az alkalmazott nyelvészet köréből, 2017: XI. Alkalmazott Nyelvészeti Doktoranduszkonferencia. MTA Nyelvtudományi Intézet, Budapest, 39-49.

Ekman, Paul-Friesen, Wallace (1969): The repertoire of nonverbal behavior: Categories, origins, usage, and coding. Semiotica, 1., 49-98.

Enli, Gunn (2017): Twitter as arena for the authentic outsider: exploring the social media campaigns of Trump and Clinton in the 2016 US presidential election. European Journal of Communication, Vol. 32, No. 1, 50-61. https://doi.org/10.1177/0267323116682802

Fiorina, Morris P. (1976): The Voting Decision: Instrumental and Expressive Aspects. Journal of Politics, Vol. 38, No. 2, 390-413.

Fischer-Lichte, Erika (1990): Geschichte des Dramas. A. Francke Verlag, Tübingen-Basel.

Gerencsér Péter-Szúts Péter (2020): A Társadalmi nyilvánosság webkettes szerkezetváltozása. JelKép, 2002/2. 38-51. https://doi.org/10.20520/JEL-KEP.2020.2.39 
Gentile, Douglas A. (2013): Catharsis and Media Violence: A Conceptual Analysis. Societies, Vol 3, No. 4, 491-510. https://doi.org/10.3390/soc3040491

Gerő András szerk. (2001): Antiszemita közbeszéd Magyarországon 2000-ben. Budapest: B’ nai B’ rith Első Budapesti Közösség.

Glózer Rita (2013): A „cigányok“ mint ellenség diszkurzív konstrukciói a hazai online szélsőjobboldali médiában, In: (szerk.): Bogdán Mária, Feischmidt Margit, Guld Ádám: „Csak másban“: Romareprezentáció a magyar médiában. Gondolat-PTE Kommunikáció- és Médiatudományi Tanszék, Budapest-Pécs, 123-140.

Goffman, Erving (2000): Az én bemutatása a mindennapi életben. Thalassa Alapítvány, Pólya Kiadó, Budapest.

Habermas, Jürgen (2011) A kommunikatív cselekvés elmélete. Gondolat, Budapest.

Hamlin, Alan-Jennings, Colin (2011): Expressive Political Behaviour: Foundations, Scope and Implications. British Journal of Political Science. Vol. 41, No. 3., 645-670. https://doi.org/10.1017/ S0007123411000020

Haselmayer, Martin-Jenny, Marcelo (2017): Sentiment analysis of political communication: Combining a dictionary approach with crowdcoding. Quality and Quantity, Vol. 51, No. 6, $2623-$ 2646. https://doi.org/10.1007/s11135-016-0412-4.

Hermann Róbert (2010): Programvita és obszcenitás. Andrássy Gyula gróf és Dessewffy Emil gróf politiko-pornografikus verses üzenetváltása 1848 elején (avagy, mindig lehet lejjebb). Aetas, 25. évf., 2. szám, 155-166.

Jakobson, Roman (1960): Linguistics and Poetics. In: T. Sebeok (ed.): Style in Language, M.I.T. Press, Cambridge. 1-27.

Jerit, Jennifer-James H. Kuklinski-Paul J. Quirk (2009): Strategic Politicians, Emotional Citizens, and the Rhetoric of Prediction. In: Borgida, Eugene-Christopher M Federico-John L. Sullivan (eds.): The Political Psychology of Democratic Citizenship, Oxford University Press. 100-124.

Kalpokas, Ignas (2019): A Political Theory of Post-Truth. Palgrave Macmillan.

Kariryaa, Ankit-Rundé, Simon-Heuer, Hendrik-Jungherr, Andreas-Schöning, Johannes (2020): The Role of Flag Emoji in Online Political Communication. Social Science Computer Review. https:// doi.org/10.1177/0894439320909085

Kim, Heejung-Sherman, David (2007): "Express yourself": Culture and the effect of self-expression on choice. Journal of Personality and Social Psychology, Vol 92, No 1, 1-11. https://doi. org/10.1037/0022-3514.92.1.1.

Kiss Balázs (2013) Érzelmek és politikatudomány. Politikatudományi Szemle, Vol. 23, No. 3, 7-28.

Koschut, Simon (2017): The power of (emotion) words: on the importance of emotions for social constructivist discourse analysis in IR. Journal of International Relation Development, 21: 495522. https://doi.org/10.1057/s41268-017-0086-0

Koschut, Simon (2018): No sympathy for the devil: Emotions and the social construction of the democratic peace. Cooperation and Conflict, Vol 53, No. 3, 320-338. https://doi.org/10.1177/ 0010836717737570

Kövecses, Zoltán (2003): Metaphor and Emotion. Language, Culture, and the Body in Human Feeling. Cambridge University, Cambridge. 
Krekó Péter (2018): Tömegparanoia: Az összeesküvés-elméletek és álhírek szociálpszichológiája. Athenaeum Kiadó, Budapest.

Martin, Ryan-Coyier, Kelsey-VanSistine, Leah-Schroeder, Kelly (2013): Anger on the Internet: The Perceived Value of Rant-Sites. Cyberpsychology, Behavior, and Social Networking, Vol. 16, No. 2, 119-122, https://doi.org/10.1089/cyber.2012.0130

Merkovity Norbert (2018): A figyelemalapú politika a közösségi média korában: a politikai kommunikáció lehetséges értelmezése napjainkban. Médiatudományi Intézet, Budapest. (Médiatudományi könyvtár, 32.)

Mor, Yifat-Kligler-Vilenchik, Neta-Maoz, Ifat (2015): Political Expression on Facebook in a Context of Conflict: Dilemmas and Coping Strategies of Jewish-Israeli Youth. Social Media + Society. https://doi.org/10.1177/2056305115606750

Mutz, Diana C. (2015): In-Your-Face Politics. The Consequences of Uncivil Media. Princeton University Press, Princeton-Oxford.

Ober, Josiah (1991): Mass and Elite in Democratic Athens: Rhetoric, Ideology, and the Power of the People. Princeton University Press.

Ober, Josiah (1993): Public speech and the power of the people in democratic Athens. PS: Political Science and Politics, September.

Papacharissi, Zizi (2015): Affective Publics. Sentiment, Technology, and Politics. Oxford University Press, New York.

Pál Gábor (2012): A gyưlöletbeszéd fogalma a politikai vitákban. Értelmezések és alkalmazások. Studies in Political Science. Politikatudományi tanulmányok. Vol. 2, No. 2.

Péter Mihály (1984): Érzelemkifejezés, stílusérték és expresszivitás a nyelvben. Általános Nyelvészeti Tanulmányok, 15. 219-235.

Rosanvallon, Pierre (1992): Le sacre du citoyen. Histoire du suffrage universel en France. Gallimard, Párizs.

Sapir, Edward (1921): Language. An Introduction to the Study of Speech. Harcourt, Brace, New York.

Schleicher Nóra (2020): Hogy érzed magad? Autentikusság és az érzelmek nyilvánossága. JelKép, 2.

Schluchter, Wolfgang (1981): The rise of Western rationalism. University of California Press, Berkeley.

Searle, John (1979): Expression and Meaning. Studies in the Theory of Speech Acts. Cambridge University Press, Cambridge.

Searle, John (1997): Közvetett beszédaktusok. In: Pléh Csaba-Síklaki István-Terestyéni Tamás (szerk.): Nyelv - kommunikáció - cselekvés. Osiris Kiadó.

Searle, John (2009): Beszédaktusok. Nyelvfilozófiai tanulmány. Alkalmazott Kommunikációtudományi Intézet-Gondolat Kiadó, Budapest.

Smith, Barry (1990): Towards a History of Speech Act Theory. In: A. Burkhardt (ed.): Speech Acts, Meanings and Intentions. Critical Approaches to the Philosophy of John R. Searle. de Gruyter, Berlin-New York.

Spohr, Dominic (2017): Fake news and ideological polarization: Filter bubbles and selective exposure on social media. Business Information Review, Vol. 34, No. 3. 150-160. 
Stanyer, James (2005): The British public and political attitude expression: the emergence of a selfexpressive political culture? Contemporary Politics, Vol. 11, No. 1, 19-32. https://doi.org/10. 1080/13569770500098623

Sydnor, Emily (2019): Disrespectful Democracy. The Psychology of Political Incivility. Columbia University Press, New York.

Szabó Gabriella - Kiss Balázs (2012): Trendek a politikai kommunikációban. Magyarország az ezredfordulón. In: Boda Zsolt-Körösényi András (szerk): Van irány? Trendek a magyar politikában. $110-127$.

Tátrai Szilárd (2011): Bevezetés a pragmatikába. Funkcionális kognitív megközelítés. Tinta Könyvkiadó, Budapest.

Tátrai Szilárd (2017): Pragmatika. In: Tolcsvai Nagy Gábor (szerk.) Nyelvtan. Osiris Kiadó, Budapest.

Taylor, Charles (1985): Language and Human Nature. In: Taylor, Charles: Human Agency and Language. Philosophical Papers 1. Cambridge University Press, Cambridge.

Voggeser, Birgit-Ranjit K. Singh-Anja S. Göritz (2018): Self-control in Online Discussions: Disinhibited Online Behavior as a Failure to Recognize Social Cues. Frontiers in Psychology, 8. Walker, Jeffrey (2000): Rhetoric and Poetics in Antiquity. Oxford University Press, New York.

Weber, Max (1987): Gazdaság és társadalom, 1. Közgazdasági és Jogi Könyvkiadó, Budapest.

Wünsche, Isabel (2018): The Routledge Companion to Expressionism in a Transnational Context. Routledge, London.

Yuval-Davis, Nira (2011): The politics of belonging: intersectional contestations. Sage, London.

Zhao, Shanyang-Sherri Grasmuck-Jason Martin (2008): Identity construction on Facebook: Digital empowerment in anchored relationships. Computers in Human Behavior, Vol. 24, No. 5, $1816-$ 1836. https://doi.org/10.1016/j.chb.2008.02.012

Zombory Máté (2019): Traumatársadalom. Az emlékezetpolitika történeti-szociológiai kritikája. Kijárat Kiadó. 